\title{
Life in Doggerland - palynological investigations of the environment of prehistoric hunter-gatherer societies in the North Sea Basin
}

\author{
Sascha Krüger ${ }^{1}$, Walter Dörfler ${ }^{1}$, Ole Bennike ${ }^{2}$, Steffen Wolters ${ }^{3}$
}

How to cite:

KRÜGer, S., DöRfler, W., Bennike O. ¿ Wolters, S. (2017): Life in Doggerland - palynological investigations of the environment of prehistoric hunter-gatherer societies in the North Sea Basin. - E\&G Quaternary Science Journal, 66 (1): 3-13. DOI: 10.3285/eg.66.1.01

\begin{abstract}
:
Analyses of two vibrocores from the sea floor of the submerged Doggerland within the centre of the North Sea provide a record of late Pleistocene and early Holocene vegetation history. Based on two high-resolution pollen diagrams of basal peat, the vegetation development and past environmental conditions were studied. The diagrams show that the vegetation history of Doggerland corresponds to that of the north European Plain during the late glacial and early Holocene. The concentration of micro-charcoal was determined, but no traces of human activity were found.
\end{abstract}

Leben in Doggerland - palynologische Untersuchungen zur Umwelt urgeschichtlicher Jäger- und Sammlerkulturen im heutigen Nordseebecken

Kurzfassung:

Die Analyse zweier Bohrkerne von Grund der Nordsee und dem in Analogie mit Doggerland bezeichneten ehemaligen Nordseefestland boten die Möglichkeit eines besseren Verständnisses pleistozäner und frühholozäner Vegetationsgeschichte. Basierend auf hochauflösenden Pollendiagrammen an Basalen Torfen wurden Vegetationsentwicklungen und Umweltbedingungen untersucht. Die Diagramme zeigen, dass sich die Mitteleuropäische Grundsukzession in weiten Teilen nachverfolgen lässt. Eine Bestimmung der Holzkohlekonzentrationen wurde vorgenommen, jedoch konnten keine sicheren Nachweise für menschliche Aktivität erbracht werden.

Keywords: $\quad$ Doggerland, North Sea Basin, pollen analysis, basal peat, Pleistocene-Holocene Transition, hunter-gatherers

\begin{abstract}
Address of the cor-
Sascha Krüger, Centre for Baltic and Scandinavian Archaeology, Stiftung Schleswig-Holsteinische Landesmuseen, Schloss Gotresponding author:

\section{Introduction}

The former land area in the North Sea region, named Doggerland by Coles (1998) has for long been considered a potential settlement area of Palaeolithic and Mesolithic hunter-gatherer societies. Regardless of their low number, finds of retouched flint artefacts and harpoons are indisputable evidence of former human presence. Countless mammal bones are witness of a rich and changing environment (BJERCK 1995: 132; Coles 1998: 47; GLiMMERVEen et al. 2006: 242; Peeters \& Momber 2014: 55; Schwabedissen 1951: 76).

A systematic archaeological exploration of Doggerland is obviously impossible because the area is now submerged. However, the history of the region can be studied by palaeoecological methods. Here we used palynology, a

1 Christian-Albrechts University Kiel

2 Geological Survey of Denmark and Greenland (GEUS)

3 Lower Saxony Institute for historical coastal research (NIhK) particular consideration of non-pollen-palynomorphs and the counting of micro-charcoal of two sediment cores from the bottom of the North Sea (fig. 1) to throw light on the development of this region, where classical archaeological methods are of limited value.

One of the questions we wanted to investigate is what were the living conditions in Doggerland at the Pleistocene-Holocene transition and what was the impact of submergence on potential settlement areas?

The combination of rising temperatures and consequently melting ice sheets during the late glacial and early Holocene resulted in a rise of the sea level. The simultaneously rising groundwater level close to coastal areas caused fen formation in wide areas in the hinterland of the coast, and the so called basal peats developed (BEHRE 2008: 21; Behre et al. 1979: 94; Firbas 1952: 146; JANSEN et al. 1979: 182; LANGE \& Menke 1967: 30; Overbeck 1975: 46). The permanent rising sea level led inevitably to submergence of coastal fens that hence were often eroded by the sea. Big lumps of peat - the so called moorlogs - that once 


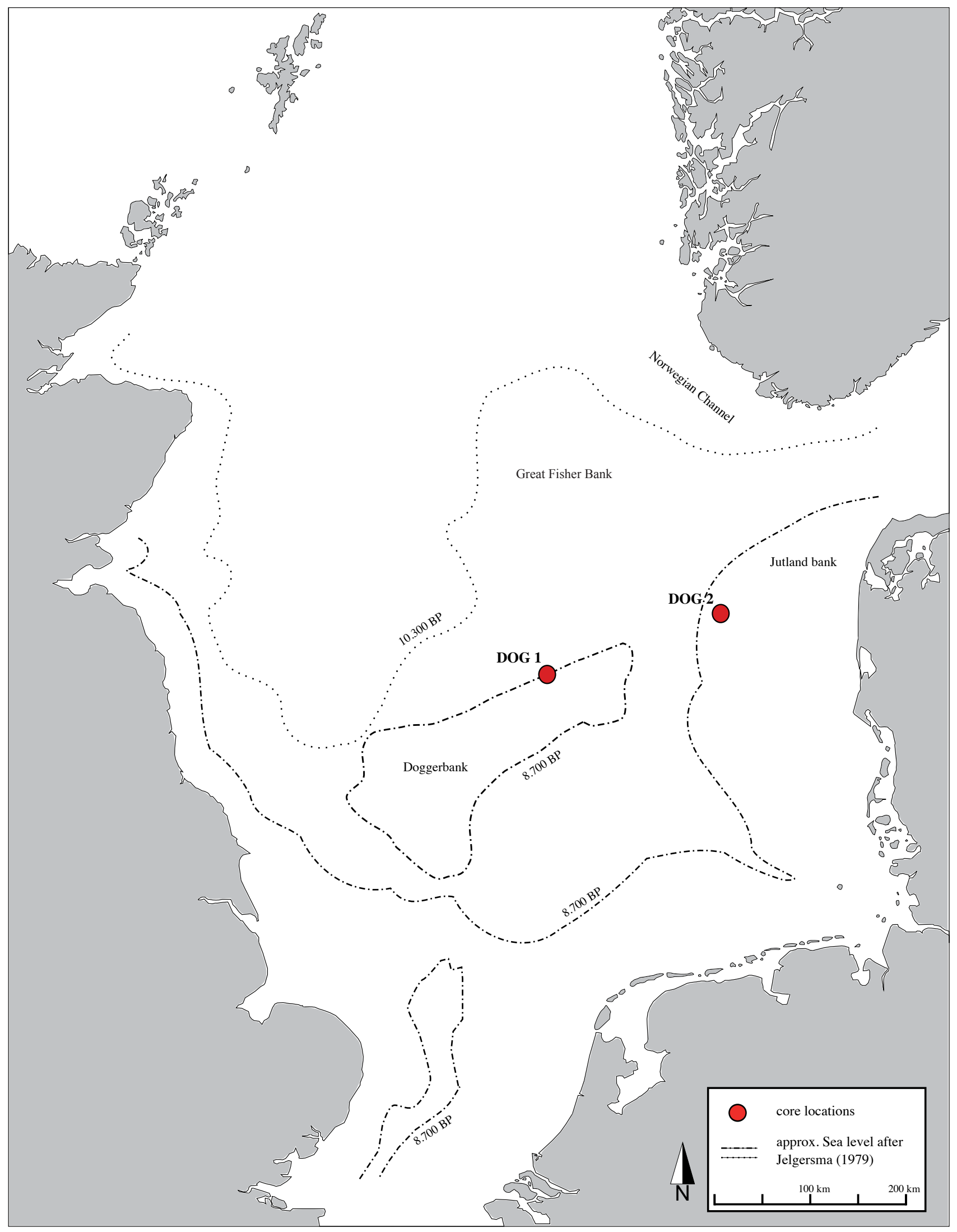

Fig. 1: Geographical setting of the cored locations with estimated sea level for the Preboreal and Boreal period.

Abb. 1: Geografische Position der Bohrstandorte mit ungefährem Verlauf der Küstenlinie während des Präboreals und Boreals.

were part of the basal peat layer are often found in the nets by fishermen. Such lumps of peat may result from erosion of peat layers (ERDTMAN 1924; WHITEHEAD \& GOODCHILD 1909). An aim of this investigation is to reconstruct the peat formation at the cored locations in order to reason out whether these are basal peats.

Micro-charcoal in pollen samples can shed light on climate induced fires in the natural ecosystem but may also 
be used to infer man-made changes (KANGUR 2002: 289; Moore 1996: 63; TipPING 1996). Assured evidence of human activity during the Mesolithic is mostly associated with high amounts of micro-charcoal in the pollen record. In many parts of Scotland, the Shetland Islands and northern Germany early Holocene forest opening and high quantities of micro-charcoal are correlated and discussed as evidence of anthropogenic activities (EDWARDS 1996: 34-36; EDWARDS \& SUGDEN 2009: 15; INNES et al. 2013: 88; TIPPING 1996: 45; Robin \& Nelle 2014: 62; Welinder 1985). At the Mesolithic site of Hohen Viecheln (Mecklenburg-western Pomerania, Germany) “... finds of micro-charcoal can be referred to fires of Mesolithic people...” (Schmitz 1961: 31). Against this background we wanted to find an explanation for the given signal from micro-charcoal. Is it possible to find evidence of anthropogenic activity and human-environment-interactions based on pollen- and micro-charcoal counting even long before the Neolithic period?

\section{Geographical setting}

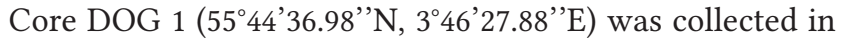
the centre of the North Sea at the northern edge of the Dogger Bank at a water depth of $38.8 \mathrm{~m}$. The coring position of DOG $2\left(56^{\circ} 20.788^{\prime} \mathrm{N}, 6^{\circ} 6.615^{\prime} \mathrm{E}\right)$ is located $200 \mathrm{~km}$ closer to the west coast of Jylland near the Lille Fisker Banke at a depth of $42.1 \mathrm{~m}$. According to the relative sea-level curves of Behre (2003), Streif (2004) and Jelgersma (1979) both settings must have been flooded during the second phase of the late Weichselian and Holocene North Sea transgression. During this phase areas from about 72 to $25 \mathrm{~m}$ below present-day sea level were inundated (fig. 1).

\section{Material}

Based on a number of pollen analyses (BEHRE \& MENKE 1969; MENKE 1996; Wolters et al. 2010) and pioneering studies of submerged peat beds (REID 1913; WHITEHEAD \& GOODCHILD 1909) as well as more recent geological investigations, it is well-known that during the Preboreal and Boreal basal peats were deposited in wetland areas in the North Sea. In some areas such peats have been preserved from erosion during the transgression. In contrast to sandy and clayey sediments, peat provides good conditions for preservation of pollen

Tab. 1: lithological description of DOG 1 (top core edge -38,8 m NN) Tab. 1: Lithologische Beschreibung des Kerns DOG 1 (Kernoberkannte $-38,8 m \mathrm{NN})$.

\begin{tabular}{|l|l|}
\hline Depth [cm] & Lithology \\
\hline $0-12$ & $\begin{array}{l}\text { Medium to coarse grained sand, interspersed with shells } \\
\text { and many small stones, calcareous, 7.5YR N7 olive-grey }\end{array}$ \\
\hline $12-58$ & Clayey sediments, calcareous, 5Y 4.1 dark grey \\
\hline $58-62$ & $\begin{array}{l}\text { Clayey sediments and peat, gradual transition to peat } \\
\text { below, 10YR 3.1-4.1 very dark grey }\end{array}$ \\
\hline $62-73$ & $\begin{array}{l}\text { Peat, highly compressed, no organic macro-remains } \\
\text { visible, partly sand lenses, 10 YR 2.1 black }\end{array}$ \\
\hline $73-86$ & $\begin{array}{l}\text { Fine to medium grained sand, sharp transition, 2.5Y } \\
\text { 4.2 dark grey-brown }\end{array}$ \\
\hline $86-100$ & Fine to medium grained sand, 2.5Y 5.3 light olive-brown \\
\hline
\end{tabular}

Tab. 2: lithological description DOG 2 (top core edge - $42.1 \mathrm{~m} \mathrm{NN}$ ) Tab. 2: Lithologische Beschreibung des Kerns DOG 2 (Kernoberkannte $-42,1 m N N)$.

\begin{tabular}{|l|l|}
\hline Depth [cm] & Lithology \\
\hline $0-110$ & $\begin{array}{l}\text { Medium-grained homogenous sand, calcareous, with } \\
\text { scattered shells of marine molluscs, 5Y 5/2 olive grey. } \\
\text { Lower boundary erosive }\end{array}$ \\
\hline $110-504$ & $\begin{array}{l}\text { Bioturbated clay, calcareous, 5Y 4/1 dark grey. Lower } \\
\text { boundary sharp }\end{array}$ \\
\hline $504-515$ & $\begin{array}{l}\text { Peat, in situ roots from the top to the bottom, 2.5Y N2 } \\
\text { black. Lower boundary sharp }\end{array}$ \\
\hline $515-530$ & $\begin{array}{l}\text { Sandy silt with small sand lenses, 10YR 2.1 black. } \\
\text { Lower boundary sharp }\end{array}$ \\
\hline $530-535$ & $\begin{array}{l}\text { Medium-grained sand, 2.5Y 4.2 dark grey-brown. } \\
\text { Lower boundary sharp }\end{array}$ \\
\hline $535-540$ & $\begin{array}{l}\text { Medium-grained sand with scattered pebbles, 2.5Y 6.2 } \\
\text { light brown-grey }\end{array}$ \\
\hline
\end{tabular}

grains. In both cores preliminary investigations confirmed that pollen grains were well preserved, and hence it was decided to conduct a high-resolution study of the peat deposits. Both sediment cores were sampled with a vibrocorer. Samples from core DOG 1 were provided by the Lower Saxony Institute for Historical Coastal Research (cored by the Federal Institute for Geoscience and Natural Resources within the project Geopotential of the German North Sea - Marine CSEM and provided for further research before) and DOG 2 by the Geological Survey of Denmark and Greenland. The sediment successions extend into the Pleistocene at the bottom of the cores. The sediment stratigraphy of the cores is shown in Table 1 and 2.

\section{Methods}

\subsection{Sampling and sample treatment}

Both cores were sub-sampled at $5 \mathrm{~mm}$ intervals throughout the peat sections. The clay, silt and sand sections were sampled at least at $2 \mathrm{~cm}$ intervals. Sample preparation was carried out according to standard techniques (FÆGRI \& IVERSEN 1989: 76-84; acetolysis after ERDTMANN 1960: 561-62). A Lycopodium spore tablet was added to each sample to calculate pollen and charcoal concentrations (STOCKMARR 1971). Pollen counting was performed at a total magnification of $\times 400$ for routine counting and $\mathrm{x} 1000$ for critical objects. A total pollen sum of at least 300 TTP (total terrestrial pollen) and if possible 500 TTP was achieved. Pollen grains were identified with the help of literature, mainly BEUG (2004), FÆGRI (1993) and Moore (et al. 1991). A reference collection at the Institute of Pre- and Protohistoric Archaeology in Kiel was also used. Micro-charcoal was counted as a possible indicator of human activity (WARREN et al. 2014: 630; BEHRE 1988: 637; Tipping 1996: 40). Charcoal particles $>10 \mu \mathrm{m}$ were identified by asymmetric shape, deep black colour and sharp fraction edges (PATTERSON et al. 1987: 9; Wiethold 1997: 48). Considering the multiple fractioning caused during the preparation process sizing was neglected.

The pollen diagrams were constructed using the CountPol software developed by I. Feeser, University of Kiel. Percentage values shown in the diagrams were calculated based on 


\begin{tabular}{|l|l|l|l|l|}
\hline Depth [cm] & Lab. no & $\mathbf{\delta}^{13} \mathbf{C}$ & ${ }^{14}$ C age & cal. years BP [2 $\mathbf{\sigma}]$ \\
\hline$[$ DOG 1] & & & & \\
\hline $63.0-64.0$ & POZ-47110 & $-28,8 \pm 0,3$ & $9068 \pm 44$ & $10366-10173$ \\
\hline $72.0-73.0$ & POZ 47111 & $-31,6 \pm 0,2$ & $9954 \pm 52$ & $11620-11240$ \\
\hline$[$ DOG 2] & & & & \\
\hline $506.5-507.0$ & KIA-51169 & $-27,96 \pm 0,17$ & $9547 \pm 60$ & $11101-10701$ \\
\hline $510.5-511.0$ & KIA-51170 & $-30,19 \pm 0,35$ & $9311 \pm 51$ & $10664-10298$ \\
\hline $513.0-513.5$ & KIA-51171 & $-29,43 \pm 0,14$ & $9505 \pm 51$ & $11083-10593$ \\
\hline
\end{tabular}

Tab. 3: radiocarbon ages from DOG 1 and 2

Tab. 3: Radiokarbonalter von DOG 1 und 2.

\begin{tabular}{|c|c|c|c|}
\hline PAZ & depth $[\mathrm{cm}]$ & pollen analytical key features & period \\
\hline $3 b$ & $38.0-58.5$ & $\begin{array}{l}\text { Corylus rise, Pinus dominates, Quercus, Alnus Ulmus continuous below 5\%, Spar- } \\
\text { ganium-type, Pediastrum, Botryococcus continuously present }\end{array}$ & Boreal \\
\hline 3a & $58.5-62.25$ & $\begin{array}{l}\text { drop of Corylus, Betula min., Pinus increase, Ulmus, Alnus, Quercus }<5 \% \text { Cheno- } \\
\text { podiaceae, Sparganium-type, Cyperaceae, Pediastrum slowly increase, Calluna } \\
\text { and Sphagnum decrease }\end{array}$ & Boreal \\
\hline $2 b$ & $62.25-65.75$ & drop of Betula, strong rise and max. of Corylus, Poaceae min. & Boreal \\
\hline $2 a$ & $65.75-73.5$ & $\begin{array}{l}\text { Betula max., continuous presence of Corylus with an enhanced rise towards the } \\
\text { end, Calluna and Sphagnum increase above } 10 \% \text {, Poaceae steeply decrease }\end{array}$ & Preboreal \\
\hline 1 & $73.5-78.0$ & decrease of Pinus, rise of Betula towards the end, Poaceae max., Calluna rise & $\begin{array}{l}\text { c.f. Younger } \\
\text { Dryas }\end{array}$ \\
\hline
\end{tabular}

Tab. 4: DOG 1 pollen assemblage zones with key features Tab. 4: DOG 1 Pollensammelzonen mit Hauptmerkmalen.

\begin{tabular}{|l|l|l|l|}
\hline PAZ & depth [cm] & pollen analytical key features & period \\
\hline 4b & $490.0-495.75$ & $\begin{array}{l}\text { Pinus dominant, closed Quercus and Ulmus curves, Sparganium-type, Pediastrum } \\
\text { and Botryococcus curves closed, Ilex and Tilia occure }\end{array}$ & Boreal \\
\hline 4a & $495.75-505.75$ & $\begin{array}{l}\text { Pinus rises and reaches max., Betula slowly drops, Ulmus and Quercus curves } \\
\text { partly closed but below 5\%, Poaceae increase, Sparganium-type, Equisetum [part- } \\
\text { ly], Pediastrum and Botryococcus curves are closed }\end{array}$ & Boreal \\
\hline 3b & $505.75-509.75$ & slow rise of Pinus, Cyperaceae max., Poaceae max., Quercus and Ulmus occure & Boreal \\
\hline 3a & $509.75-514.5$ & $\begin{array}{l}\text { Betula 30 \%, Pinus 20 \%, Corylus continuous but below 15\%, Poaceae increase, } \\
\text { Filipendula max. }\end{array}$ & $\begin{array}{l}\text { Preboreal/ } \\
\text { Boreal }\end{array}$ \\
\hline 2 & $514.5-521.0$ & $\begin{array}{l}\text { Betula min., no other AP as Betula, Pinus and Picea, Poaceae min., Cyperaceae } \\
\text { min. }\end{array}$ & $\begin{array}{l}\text { c.f. Younger } \\
\text { Dryas }\end{array}$ \\
\hline 1 & $521.0-528.0$ & $\begin{array}{l}\text { Pinus max., low values of Betula, Poaceae and Cyperaceae [generally bad preser- } \\
\text { vation] }\end{array}$ & $\begin{array}{l}\text { c.f. Younger } \\
\text { Dryas }\end{array}$ \\
\hline
\end{tabular}

Tab. 5: DOG 2 pollen assemblage zones with key features Tab. 5: DOG 2 Pollensammelzonen mit Hauptmerkmalen.

the total terrestrial pollen sum. The diagrams were imported to Inkscape (vers. 0.91-1) where zone boundaries were drawn and minor modifications were made. Zone boundaries were placed at marked changes in pollen assemblages.

\section{$4.2{ }^{14} \mathrm{C}$-dating}

Two ${ }^{14} \mathrm{C}$ ages of bulk sediment samples from DOG 1 were available at the beginning of this project. In DOG 2 no suitable seeds or fruits for dating could be found. Hence, three bulk samples were taken. The dates were calibrated using the calibration programme OxCal 4.2 (BRONK RAMSEY 2009) and the IntCal13 dataset (REIMER et al. 2013). The results are found in Table 3.

\section{Results}

\subsection{Pollen analysis}

The pollen diagram DOG 1 (fig. 2) is based on 33 pollen spectra between 38.0 and $78.0 \mathrm{~cm}$. The diagram was divided into five pollen assemblage zones. DOG 2 includes 55 pollen spectra between 490.0 and $528.0 \mathrm{~cm}$. The diagram DOG 2 (fig. 3) was divided into six pollen assemblage zones. Their main features are compiled in Table 4 and 5.

The pollen diagram DOG 1 spans the chronozones of the Younger Dryas, Preboreal and Boreal. The development of an open birch forest and mass-expansion of hazel are pollen stratigraphical events that allow a chronological classification. The vegetation of the Younger Dryas was dominated by grasses and can be characterized as tundra vegetation. It is conspicuous that juniper (funiperus) and mugwort (Artemisia) are underrepresented or not present in this chronozone. The transition to the early Holocene is documented by a shift in vegetation. Tree birches occupied favourable habitats in the region and formed an open forest interspersed with pines during the course of the Preboreal. On a local scale the development of a groundwater influenced wet heathland can be inferred.

The onset of the Boreal is indicated by mass-expansion of hazel and a drop of birch. A conspicuous change in the local vegetation can be observed at the transition from 


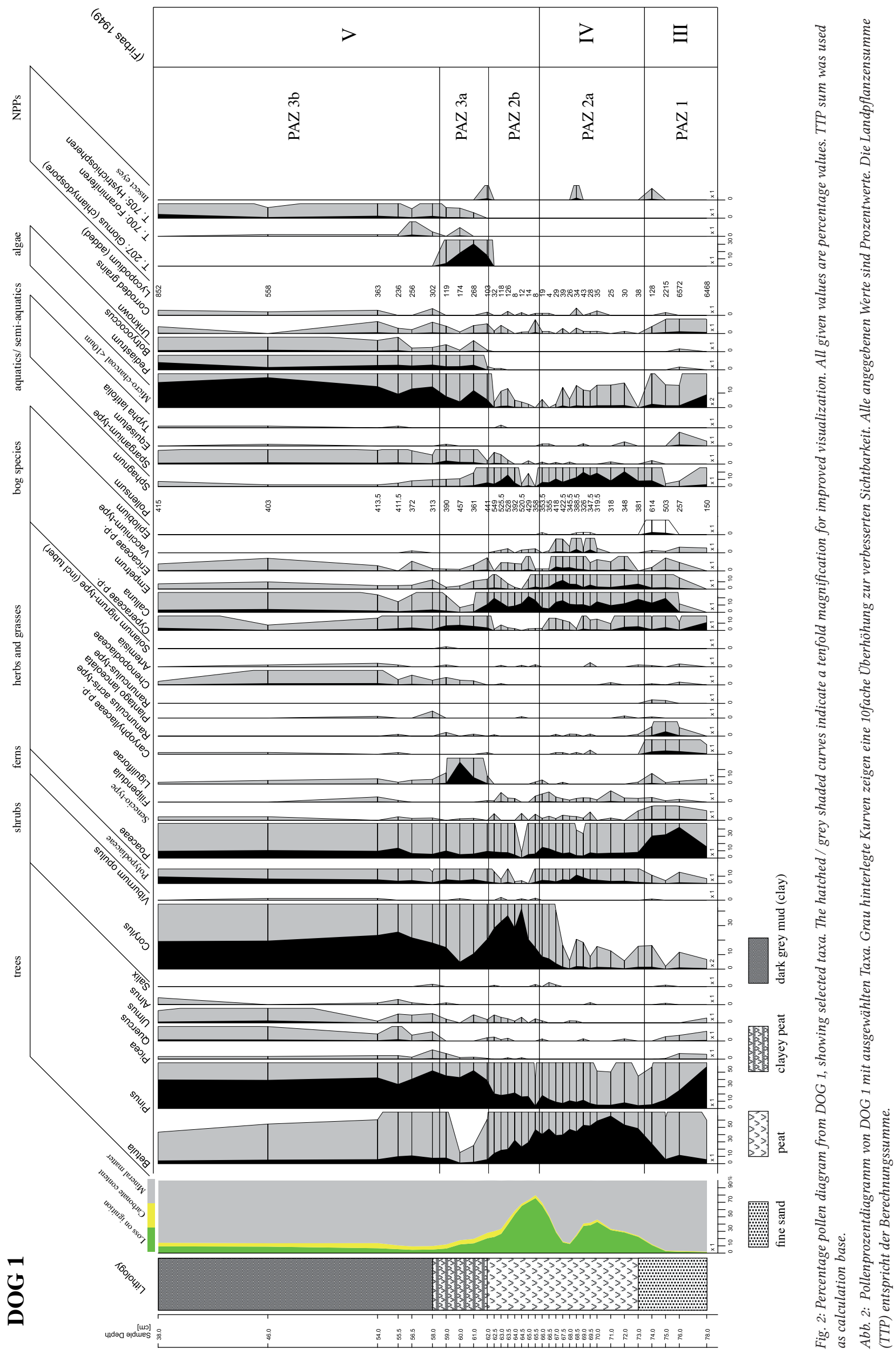




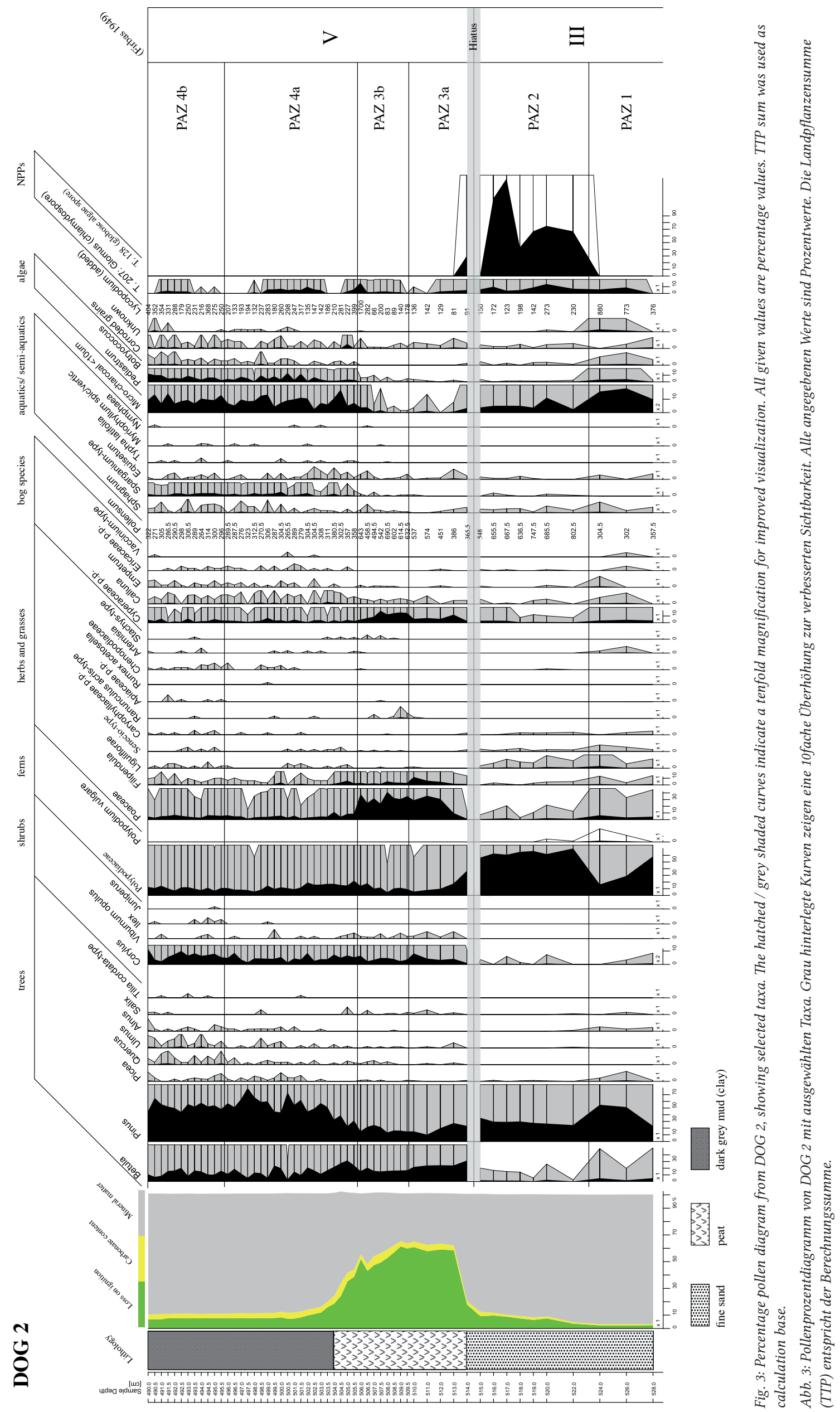


PAZ 2b to PAZ 3a. Heather and peat moss steeply decrease and at the same time lacustrine species such as bur-reed (Sparganium-type) and green algae such as Botryococcus or Pediastrum appear, indicating the formation of a freshwater lake. Non-pollen-palynomorphs indicating marine influence, such as foraminifera and hystrichospheres are recorded (BAKKER \& VAN SMEERDIJK 1982: 150), indicating that the marine inundation of the North Sea is seen in the investigated core section.

The pollen diagram DOG 2 most probably spans the chronozones of the Younger Dryas and the Boreal. A hiatus complicates the interpretation. The immigration of species of the mixed oak forest and the continuous presence of hazel are used as pollen stratigraphic events. The early Holocene development with open birch forests and the Boreal hazel maximum is not registered in the pollen diagram.

The local vegetation of the Younger Drays was most probably dominated by ferns, grasses and dwarf shrubs. The high pine pollen percentage values may indicate local pine stands. However, pine pollen are produced in huge numbers and dispersed very well by wind, and it is also possible that the pine pollen represent long-distance transport of pollen from pine forests to the south. In Denmark numerous macrofossil studies of Younger Dryas sediments have failed to show local presence of pine (MORTENSEN et al. 2014). Nothing can be said about the Preboreal vegetation at this locality due to a hiatus. Also the onset of the Boreal is not recorded, it would be expected between PAZ 2 and PAZ 3. PAZs $3 a$ to $4 \mathrm{~b}$ is referred to the Boreal because of decreasing birch pollen quantities, a continuous presence of hazel and the presence of elm, oak and alder. Pollen taxa like Poaceae (grasses), Cyperaceae (sedges) and Salix (willow) indicate a fen development until PAZ 4a. A marked change in local vegetation during the Boreal period can be seen at the transition between PAZ 3b and PAZ $4 \mathrm{a}$. Lacustrine taxa such as bur-reed, green algae like Botryococcus and Pediastrum increase and even water lily occur. Again the formation of a fresh-water lake can be assumed. The diagram shows no evidence of the marine inundation.

\subsection{Chronology}

Peat formation occurred at location DOG 1 mainly during the Preboreal and partly during the Boreal period according to the composition of pollen taxa. The radiocarbon ages confirm this assumption and specify the time of peat formation to between about 11,620 and 10.170 cal. years BP.

At core location DOG 2 the time of peat formation is less clear. On one hand the pollen composition indicates that peat formed during the Boreal period but a hiatus complicates the interpretation of the pollen diagram. On the other hand three radiocarbon samples yielded ages between 11,100 and 10,300 cal. years BP - equivalent to the Preboreal period but the three dates are inverted. However, it is possible that the radiocarbon ages are influenced by a reservoir effect, which can give too old ages. It is also possible that the pollen diagram reflects a very local vegetation development. A large proportion of pollen in peat deposits may come from plants growing at the core site.

In any case the quantity and quality of the ${ }^{14} \mathrm{C}$ dates do not allow the reconstruction of a reliable age-depth model.
However, it is clear that peat formation at the core locations occurred during the very early Holocene.

\section{Discussion}

\subsection{Peat formation}

As the investigated peat layers are of early Holocene origin, dating as well as lithology and the reconstructed local vegetation reassure the assumption that DOG 1 contained in-situ basal peat. A hiatus and an inversion of ${ }^{14} \mathrm{C}$ dates do not allow the same assertion for DOG 2.

The pollen diagrams DOG 1 and 2 contain indications for the development of fresh-water lakes with bur-reed, green algae or water lilies. In both cases there is a change in the sediment composition from peat to clay at the same time. For both locations it can be assumed that peat developed in coastal depressions which in the course of the Boreal period were flooded by the permanently rising groundwater level before they were covered by marine clay. This process is also seen in the Baltic Sea region in Mecklenburg-western Pomerania, Germany. Here, the Littorina transgression first led to the development of coastal fens. These were subsequently flooded due to the permanent sea level rise (Michaelis 2002: 120). Peats in this case represent an elevation above sea level. Marine influence indicated through inundation and submergence show the vicinity to the sea. Hence, this study provides two more points to the sea-level curve of the southern North Sea.

In the case of DOG 1 and 2 grasses, sedges and species from the goosefoot family can be seen as evidence for coastal influence. Constantly occurring hystrichospheres indicates occasional incursions of seawater into the freshwater system. However, the permanent presence of green algae and bur-reed that are intolerant to salt water, excludes total marine inundation at both locations during the time of peat deposition.

\subsection{The abundance of hazel}

The pollen diagram DOG 1 contains maximum values of $40 \%$ Corylus. Diagrams from surrounding areas show similar maxima. For example, in southern Norway Prøsch-Danielsen (1993) reported 42\%, in north-western Denmark Odgaard (1994) reported 40\%, in the south-eastern North Sea Basin Menke (1996) reported 42\%, Wolters (et al. 2010) $28 \%$, and OvERBEck (1975: 447) reported $30-50 \%$ on poor sandy soils of the lower moraine area in northern Germany. This peak values are equivalent to the Boreal period in northern Europe (FIrbas 1949: 49; Dörfler \& Nelle 2008: 56; LANG 1994: 231; OverBeck 1975: 446). The highest values for Corylus in diagram DOG 2 are 7\%. The high resolution of the diagram excludes the possibility that the hazel maximum was not recorded in the sampling.

PAZ $3 \mathrm{a}$ and PAZ $4 \mathrm{~b}$ of diagram DOG 2 is referred to the Boreal period, based on the occurrence of species of the mixed oak forest. An explanation for the missing Boreal hazel maximum is most probably a hiatus in the sediment record. It is suggested that peat formation was interrupted until the Boreal. 

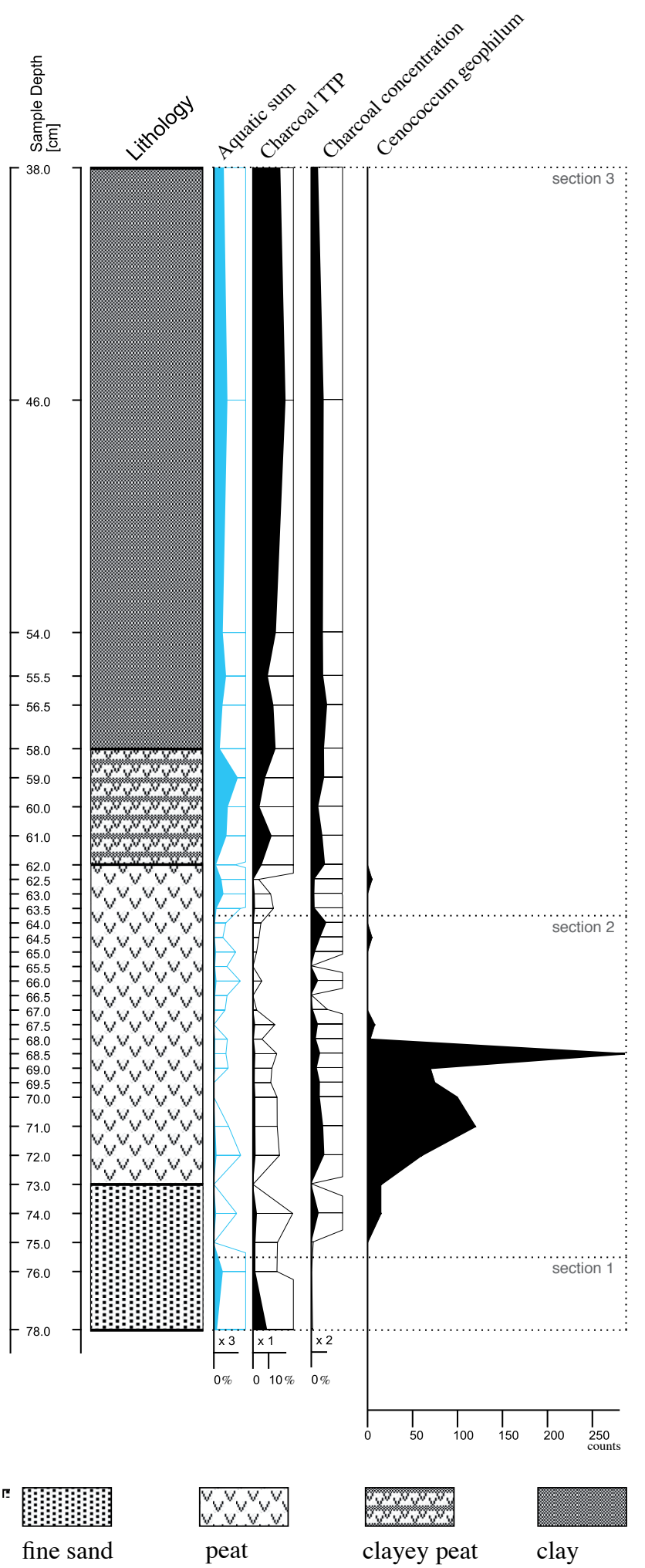

Fig. 4: Composite diagram (DOG 1) for improved interpretation of given charcoal signals. Given charcoal concentration values refer to $1 \mathrm{~cm}^{3}$ sediment.

Abb. 4: Kompositdiagramm (DOG 1) zur besseren Interpretation des Holzkohlesignals. Die angegebenen Prozentwerte der Holzkohle-Konzentration beziehen sich aufje $1 \mathrm{~cm}^{3}$ Sediment.

\subsection{Micro-charcoal as human indicator}

Both pollen diagrams presented in this article show distinct changes in the micro-charcoal record. A comparison with four parameters explains these changes (fig. 4 and 5).

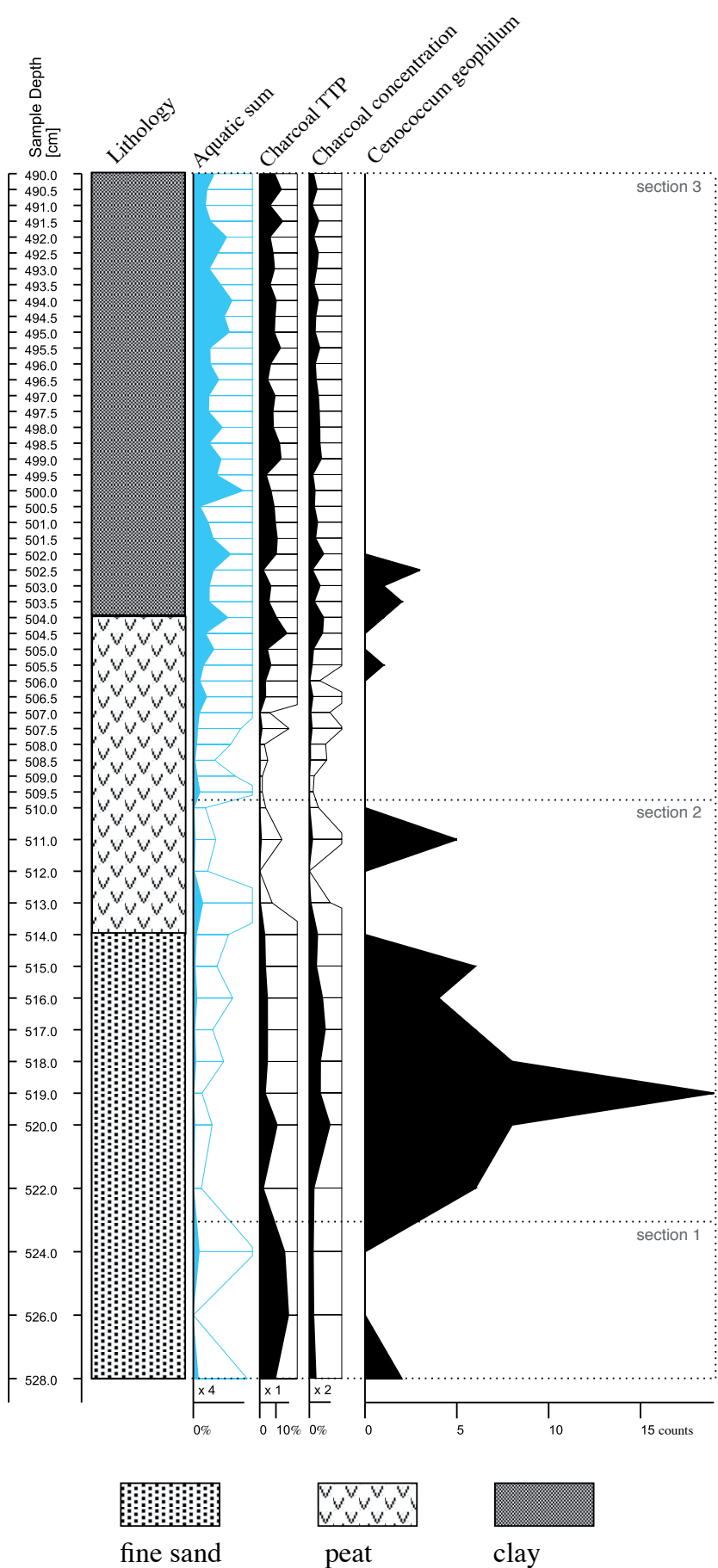

Fig. 5: Composite diagram (DOG 2) for improved interpretation of given charcoal signals. Given charcoal concentration values refer to $1 \mathrm{~cm}^{3}$ sediment.

Abb. 5: Kompositdiagramm (DOG 2) zur besseren Interpretation des Holzkohlesignals. Die angegebenen Prozentwerte der Holzkohle-Konzentration beziehen sich auf je $1 \mathrm{~cm}^{3}$ Sediment.

The blue curve shows the sum of aquatic and semiaquatic species (Typha latifolia, Spagranium-type, Equisetum, Myriophyllum, Nymphaea), not only pollen but also algae (Botryococcus, Pediastrum) and other relevant NPPs (foraminifera and hystrichosphers). The next curve displays the micro-charcoal percentage value calculated according to total terrestrial pollen (charcoal TTP). The third curve shows the micro-charcoal concentration per $\mathrm{cm}^{3}$ sediment where Lycopodium spores were used for calculation. The fourth curve shows the concentration of Cenococcum 
geophilum sclerotia per $\mathrm{cm}^{3}$ sediment. The concentration of sclerotia of this soil fungus can be used as a proxy for soil erosion (EIDE et al. 2006: 77; KROLL 1988: 111)

Both profiles presented in the figures can be divided into three sections $(1,2,3)$. In section 1 of both diagrams the micro-charcoal TTP-curve shows around $10 \%$. In contrast to that the actual micro-charcoal concentration is below 3 (DOG 2) and $1 \%$ (DOG 1). The micro-charcoal concentration curve indicates that the higher values in the microcharcoal TTP-curve are the result of a low pollen density ${ }^{4}$.

In both second sections (2) the micro-charcoal concentration in the sediment increases - an actual signal is given. In both cases these signals correlate with high concentrations of Cenococcum geophilum sclerotia in the sediment. Actually occurring fires might be the reason but most probably soil erosion indicated by Cenococcum geophilum can be assumed as source of secondary micro-charcoal.

The third section (3) shows in both cases the highest values of micro-charcoal TTP and micro-charcoal concentration. The increase in both diagrams corresponds with an increase in the aquatic species sum curve. This is the section when the development of a freshwater lake at both locations starts, as described above. It can be assumed that additionally to input by wind, water transport led to higher micro-charcoal accumulation rates. This assumption is supported by the high pine values. Pinus pollen have two air sacs and are hence more easily dispersed by wind and water than other pollen types (FIrBAs 1952: 148). Simultaneously with the increase in aquatic species the pine values increase in both of the diagrams. Increasing pine values have often been linked to inundation and some kind of bank or shore situation, respectively (BoKELMANN et al. 1981: 34).

The Boreal Chronozone is characterized by a dry and continental climate. The vegetation of north-western Europe at that time was dominated by an open birch-pineforest with strong occurrence of hazel (DOG 1\&2; BOKELMANN et al. 1981: 33; DöRFLER \& NELLE 2008: 57; OdGAARD 1994: 131; Prøsch-DANielsen 1993: 30; Overbeck 1975: 445). Macro-charcoal from Pleistocene and early Holocene deposits mainly come from pine. The combination of pinerich forests and dry climate resulted in an increased occurrence of natural fires during the Boreal period (RoBIN $\&$ Nelle 2014: 61). This circumstance and the transition from a peat bog to a shallow lake at both coring locations led to an increase in micro-charcoal.

The micro-charcoal distribution indicates that no local fire events occurred at the investigated sites. Also no phases with distinctly higher values were recorded that could have originated from human induced fires. Of course one cannot exclude anthropogenic activity and human-environment-interactions from the pollen record and the charcoal signal but according to the micro-charcoal record it is unlikely that either Palaeolithic or Mesolithic camp sites existed in the vicinity of the investigated core sites.

4 The relation between the counted Lycopodium spores and the TTP shows the pollen density (STOCKMARR 1971: 615). In the bottom part of e.g. DOG 2 this relation is 6000 to 150 .

\section{Conclusion}

Even though, artefacts or other evidence for human presence during the Palaeolithic and early Mesolithic are scarce (Coles 1999: 55; BJerCK 1995: 132; ClARK 1932: 115; 1936: 15; Louwe Kooljmans 1972: 32) it is today far more than a hypothesis that humans once crossed and lived in Doggerland. Pollen diagrams are important tools for an improved understanding of the development of this submerged region and its suitability for humans.

As suggested by Coles (1998: 63) pollen diagrams from the region show that the vegetation development followed the fundamental succession of forest development in northern central Europe. This implies that the vegetation in Doggerland equates to the vegetation of the northern European Plain during the late glacial and early Holocene. Paludification on Pleistocene mineral-rich sediment caused by a rising groundwater level and finally the development of fresh-water lakes can be inferred from both diagrams described in this paper. The beginning of the marine inundation is indicated by sporadic occurrence of indicators of marine ingressions and finally, marine clay overlies the sequence. Hence, the vicinity of the sea is evident. In addition, the results show that the quantity of micro-charcoal is at a natural level. There is no evidence of anthropogenic changes of the environment based on micro-charcoal at the core sites. Human presence is not excluded from the data but the existence of camp sites of prehistoric huntergatherers in the vicinity of the core sites seems unlikely. This result raises the question, what kind of coastal areas of Doggerland were of high importance as potential settlement areas.

\section{Outlook}

This research investigates cores from the North Sea containing peat sections. The cored sites had been part of the coast of Doggerland in the course of the early Holocene and it is often claimed that a marine orientation of the inhabitants of Doggerland is obvious (WENINGER et al. 2008: 14 ). Subsistence strategies of preboreal and boreal mesolithic hunter-gatherers and fishers and their seasonal exploitation of resources that had been obtainable in Doggerland are known from different sites in the North European Plain as e.g. Duvensee (BoKELMANN 1971; 1995; Bokelmann et al. 1981; 1985; Holst 2009; Schwantes et al. 1925). Though, camp sites of late Palaeolithic or early Mesolithic hunter-gatherers could not be proven at any of the investigated sites through the defined human indicator. It might be possible that humans that once roamed the dry North Sea area were living in lacustrine and riverine areas of the morainic landscape rather than at the highly dynamic and shifting coastline. A recent study on stable isotopes of human bones from the Southern North Sea supports this hypothesis (VAN DER PLICHT et al. 2016: 117). Hunter-gatherers of Doggerland probably sporadically frequented the seaside depending on season and availability of resources.

Nevertheless, the study area of Doggerland comprises a high potential for Palaeolithic and Mesolithic research. Further investigations, as seismic mapping (GAFFney et al. 
2007) are both desirable and necessary and can help to spot kettle holes, lagoons and former water bodies - suitable as home ranges of prehistoric people.

\section{Acknowledgements}

The authors would like to thank two anonymous reviewers for valuable comments on this manuscript. Furthermore we are also grateful to Berit V. Eriksen for her support.

\section{References}

BAKKer, M. \& VAN SMEERdIJ, D.G. (1982): A Palaeoecological Study of a Late Holocene Section from "Het Ilperveld", Western Netherlands. Review of Palaeoecology and Palynology 36: 95-163.

Behre, K.-E. \& Menke, B. (1969): Pollenanalytische Untersuchungen an einem Bohrkern der südlichen Doggerbank. - Deutsche Akademie der Wissenschaften zu Berlin. Beiträge zur Meereskunde 24/25: 122-129.

Behre, K.-E., Menke, B. \& Streif, H. (1979): The Quaternary geological development of the German part of the North Sea. Uppsala: Acta Universitatis Upsaliensis, Symposia Universitatis Upsaliensis Annum Quingentiesimum Celbrantis 2: 85-114; Uppsala (Almquist \& Wiksell).

BeHre, K.-E. (1988): The rôle of man in European vegetation history. - In Huntley, B. \& WebB, T. (eds.): Vegetation history. Handbook of vegetation science, Volume 7: 633-672; Dodrecht (Kluwer).

BEHre, K.-E. (2003): Eine neue Meeresspiegelkurve für die südliche Nordsee. Transgressionen in den letzten 10.000 Jahren. - Probleme der Küstenforschung im südlichen Nordseegebiet 28: 9-63.

BeHre, K.-E. (2008): Landschaftsgeschichte Norddeutschlands. Umwelt und Siedlung von der Steinzeit bis zur Gegenwart. - 308 S.; Neumünster (Wachholtz).

Beug, H.-J. (2004): Leitfaden der Pollenbestimmung für Mitteleuropa und angrenzende Gebiete. - 542 S.; München (Pfeil).

Bjerck, H. B. (1995): The North Sea Continent and the pioneer settlement of Norway. - In: Fischer, A. (ed.): Man and Sea in the Mesolithic. Coastal settlement above and below present sea level. Proceedings of the International Symposium, Kalundborg, Denmark 1993. Oxbow Monograph 53: 131-144; Oxford (Oxbow).

BokelmanN, K. (1971): Duvensee, ein Wohnplatz des Mesolithikums in Schleswig-Holstein und die Duvenseegruppe. - Offa. Berichte und Mitteilungen zur Urgeschichte, Frühgeschichte und Mittelalterarchäologie Bd. 28: 5-26; Neumünster (Wachholtz).

Bokelmann, K. (1995): "Faint flint fall-out": Duvensee Wohnplatz 19. Offa. Berichte und Mitteilungen zur Urgeschichte, Frühgeschichte und Mittelalterarchäologie Bd. 52: 45-56; Neumünster (Wachholtz).

Bokelmann, K., Averdieck, F.-R. \& Willkomm, H. (1981): Duvensee, Wohnplatz 8. Neue Aspekte zur Sammelwirtschaft im frühen Mesolithikum. - Offa. Berichte und Mitteilungen zur Urgeschichte, Frühgeschichte und Mittelalterarchäologie Bd. 38: 21-40; Neumünster (Wachholtz).

Bokelmann, K., Averdieck, F.-R. \& Willkomm, H. (1985): Duvensee, Wohnplatz 13. - Offa. Berichte und Mitteilungen zur Urgeschichte, Frühgeschichte und Mittelalterarchäologie Bd. 42: 13-33; Neumünster (Wachholtz).

Bronk Ramsey, C. (2009): Bayesian analysis of radiocarbon dates. - Radiocarbon 51/1: 337-360.

Clark, J.G.D. (1932): The Mesolithic Age in Britain. - 155 S.; Cambridge (University Press).

Clark, J.G.D. (1936): The Mesolithic Settlement of Northern Europe. A Study of The Food-Gathering Peoples of Northern Europe During The Early Post-Glacial Period. - 284 S.; Cambridge (University Press).

Coles, B.J. (1998): Doggerland: a Speculative Survey. - Proceedings of the Prehistoric Society 64: 45-81.

Coles, B.J. (1999): Doggerland's loss in the Neolithic. - In: Coles, B. Coles, J. \& Jørgensen, M.S. (eds.): Bog Bodies, Sacred Sites and Wetland Archaeology. Proceedings of a conference held by WARP and the National Museum of Denmark, in conjunction with Silkeborg Museum, Jutland, September 1996: 55-57; Exeter (WARP).

DörfleR, W. \& Nelle, O. (2008): A summary of the late- and post-glacial vegetation history of Schleswig-Holstein. - Mitteilungen der Arbeitsgemeinschaft für Geobotanik Schleswig-Holstein und Hamburg 65: 45-68.

EDWARDS, K.J. (1996): A Mesolithic of Western and Northern Isles of Scotland? Evidence from Pollen and Charcoal. - In: Pollard, T. \& Mor-
RISON, A. (eds.): The Early Prehistory of Scotland: 23-38; Edinburgh (Edinburgh University Press).

Edwards, K.J. \& Sugden, H. (2009): Palynological visibility and the Mesolithic Colonisation of the Hebrides, Scotland. - In: LARsson, L. (ed.): Mesolithic on the move: papers presented at the Sixth International Conference on the Mesolithic Europe 04.-08.09.2000 in Stockholm: 11-19; Oxford (Oxbow).

Eide, W., Birks, H.H., Bigelow, N.H., Peglar, S.M. ש Birks, H.J.B. (2006) Holocene forest development along the Setesdal valey, southern Norway, reconstructed from macrofossil and pollen evidence. - Vegetation History and Archaeobotany 15: 65-85

Erdtman, G. (1924): Microanalyses of "moorlog" from the Dogger Bank. - Essex Naturalist XXI: 107-112.

Erdtman, G. (1960): The Acetolysis Method. A Revised Description. Svensk Botanisk Tidskrift 54/4: 561-564.

FÆGRI, K. \& Iversen, J. (1989): Textbook of Pollen Analysis. IV Edition. 328 S.; Chichester (Wiley).

FÆGRI, K. (1993): Bestimmungsschlüssel für die nordwestdeutsche Pollenflora. - 85 S.; Jena (Fischer).

FIRBAs, F. (1949): Spät- und nacheiszeitliche Waldgeschichte Mitteleuropas nördlich der Alpen, Erster Band: Allgemeine Waldgeschichte. - 480 S.; Jena (Fischer).

FIRBAS, F. (1952): Spät- und nacheiszeitliche Waldgeschichte Mitteleuropas nördlich der Alpen, Zweiter Band: Waldgeschichte der einzelnen Landschaften. - 256 S.; Jena (Fischer).

Gaffney, V., Thomson, K. \& Fitch, S. (2007): Mapping Doggerland. The Mesolithic Landscapes of the Southern North Sea. - 131 S.; Oxford (Archaeopress).

Glimmerveen, J., Mol, D. \& van Der Pflicht, H. (2006): The Pleistocene reindeer of the North Sea - initial palaeontological data and archaeological remarks. - Quaternary International 142/143: 242-246.

Holst, D. (2009): „Eine einzige Nuss rappelt nicht im Sacke“ - Subsistenzstrategien in der Mittelsteinzeit. - Mitteilungen der Gesellschaft für Urgeschichte 18: 11-38.

InNes, J.B., Blackford, J.J. \& Rowley-Conwy, P. (2013): Late Mesolithic and early Neolithic forest disturbance: a high resolution palaeoecological test of human impact hypotheses. - Quaternary Science Reviews 77: 80-100.

JANSEN, J.H.F., vAN WEERING, T.C.E. \& EISMA, D. (1979): Late Quaternary sedimentation in the North Sea. Uppsala: Acta Universitatis Upsaliensis, Symposia Universitatis Upsaliensis Annum Quingentiesimum Celbrantis 2: 175-188; Uppsala (Almquist \& Wiksell).

Jelgersma, S. (1979): Sea level changes in the North Sea basin. Uppsala: Acta Universitatis Upsaliensis, Symposia Universitatis Upsaliensis Annum Quingentiesimum Celbrantis 2: 233-248; Uppsala (Almquist \& Wiksell).

KANGUR, M. (2002): Methodological and practical aspects of the presentation and interpretation of microscopic charcoal data from lake sediments. - Vegetation History and Archaeobotany 11: 289-294.

Kroll, H. (1988): Das Allerletzte. Cenococcum geophilum. - Archäologische Informationen. Mitteilungen zur Ur- und Frühgeschichte 11/1: 111.

LANG, G. (1994): Quartäre Vegetationsgeschichte Europas. Methoden und Ergebnisse. - 462 S.; Jena (Fischer)

LANGE, W. \& MENKE, B. (1967): Beiträge zur frühpostglazialen erd- und vegetationsgeschichtlichen Entwicklung im Eidergebiet, insbesondere zur Flußgeschichte und zur Genese des sogenannten Basistorfes. - Meyniana 17: 29-44.

Louwe Kooljmans, L.P. (1972): Mesolithic Bone and Antler Implements from the North Sea and from the Netherlands. - Berichten van de Rijksdienst voor het Oudheitkundig Bodermonderzoek 20/21: 27-73.

Ludwig, G., Müller, H. \& Streif, H. (1979): Neuere Daten zum holozänen Meeresspiegelanstieg im Bereich der deutschen Bucht. Deutsche Beiträge zur Quartärforschung in der südlichen Nordsee. Geologisches Jahrbuch A 32: 3-22.

Menke, B. (1996): Palynologische Untersuchungen des Vibrokerns Gauss 1987/5 aus der südlichen Nordsee. - Deutsche Beiträge zur Quartärforschung in der südlichen Nordsee. Geologisches Jahrbuch A 146: 177-182.

Michaelis, D. (2002): Die Talmoorgenese im Bereich der unteren Recknitz (Mecklenburg) - Moore zwischen Ostseeanstieg und autonomen Torfwachstum. - Greifswalder Geographische Arbeiten 26: 167-170.

Moore, P.D., WebB, J.A. \& Collinson, M.E. (1991): Pollen Analysis. Second Edition. - 216 S.; Oxford (Blackwell Scientific Publications).

Moore, J. (1996): Damp Squib. How to fire a major deciduous Forest in an inclement Climate. - In: Pollard, T. \& Morrison, A. (eds.): The Early Prehistory of Scotland: 62-73; Edinburgh (Edinburgh University Press). 
Mortensen, M.F., Henriksen, P.S \& Bennike, O. (2014): Living on the good soil: relationships between soils, vegetation and human settlement during the late Allerød time period in Denmark. - Vegetation History and Archaeobotany 23: 195-205.

Munsell Color (Firm). Munsell Soil Color Charts: with genuine Munsell Color Chips. Grand Rapids, MI: Munsell Color, 2010 (Print).

OdgaARd, B. V.1994: The Holocene vegetation history of northern West Jutland, Denmark. - Nordic Journal of Botany 14/4: 1-402.

Overbeck, F. (1975): Botanisch-geologische Moorkunde unter besonderer Berücksichtigung der Moore Nordwestdeutschlands als Quelle zur Vegetations-, Klima- und Siedlungsgeschichte. - 719 S.; Neumünster (Wachholtz).

Patterson, W. A., Edwards, K. J., Maguire, D. J. (1987): Microscopic Charcoal as a fossil indicator of fire. - Quaternary Science Reviews 6: 3-23.

Peeters, J.H.M. \& Momber, G. (2014): The southern North Sea and the human occupation of northwest Europe after the Last Glacial Maximum. - Netherlands Journal of Geoscience. Geologie en Mijnbouw 93 1/2: 55-70.

Prøsch-Danielsen, L. (1993): Naturhistoriske undersøgelser i Rennesøy og Finnøy kommuner, Rogaland, Sørvest-Norge. Varia 22. - 119 S.; Stavanger (Arkeologisk museum i Stavanger).

Reid, C. (1913): Submerged Forests. - 129 S.; Cambridge (University Press).

Reimer, P. J., Bard, E., Bayliss, A., Beck, J.W., Blackwell, P.G., Bronk Ramsey, C., Buck, C.E., Cheng, H., Edwards, R.L., Friedrich, M., Grootes, P.M., Guilderson, T.P., Haflidason, H., Hajdas, I. Hatté, C., Heaton, T.J., Hoffmann, D.L., Hogg, A.G., Hughen, K.A., KaISer, K.F., Kromer, B., Manning, S.W., Niu, M., Reimer, R.W., RiChards, D.A., Scott, E.M., Southon, J.R., Staff, R.A. Turney, C.S.M. \& VAN DER Plicht, J. (2013): IntCal13 and Marine13 radiocarbon age calibration curves, 0-50,000 years cal BP. - Radiocarbon 55/4: 18691887.

Robin, V. \& Nelle, O. (2014): Contribution to the reconstruction of central European fire history, based on the soil charcoal analysis of study sites in northern and central Germany. - Vegetation History and Archaeobotany 23: 51-65.

Schmitz, H. (1961): Pollenanalytische Untersuchungen in Hohen Viecheln am Schweriner See. - In: Schuldt, E. (ed.): Hohen Viecheln, ein mittelsteinzeitlicher Wohnplatz in Mecklenburg: 14-38; Berlin (Akademie Verlag).

Schwabedissen, H. (1951): Zur Besiedlung des Nordseeraumes in der älteren und mittleren Steinzeit. - In: Kersten, K. (ed.): Festschrift für Gustav Schwantes zum 65. Geburtstag: 59-77; Neumünster (Wachholtz).

Schwantes G., Gripp, K. \& Beyle, M. (1925): Der frühmesolithische Wohnplatz von Duvensee. - Prähistorische Zeitschrift 16: 173-177.

STOCKMARR, R (1971): Tablets with spores used in absolute pollen analysis. - Pollen et Spores 13: 615-621.

Streif, H. (2004): Sedimentary record of Pleistocene and Holocene marine inundations along the North Sea coast of Lower Saxony, Germany. Quaternary International 112: 3-28.

TIPpING, R. (1996): Microscopic Charcoal Records, inferred human activity and climate change in the mesolithic of northernmost Scotland. - In Pollard, T. \& Morrison, A. (eds.): The Early Prehistory of Scotland: 39-61; Edinburgh (Edinburgh University Press).

van der Plicht, J., Armkreutz, L.W.S.W., Niekus, M.J.L.Th., Peeters, J.H.M. \& SMIT, B.I. (2016): Surf'n Turf in Doggerland: Dating, stable isotopes and diet of Mesolithic human remains from the southern North Sea. - Journal of Archaeological Science: Reports 10: 110-118.

Warren, G., Davis, S., McClatchie, M. \& SAnds, R. (2014): The potential role of humans in structuring the wooded landscapes of Mesolithic Ireland: a review of data and discussion of approaches. - Vegetation History and Archaeobotany 23: 629-646.

WiETHOLD, J. (1997): Studien zur jüngeren postglazialen Vegetations- und Siedlungsgeschichte im östlichen Schleswig-Holstein: mit regionalen Pollendiagrammen aus dem Belauer See, Kr. Plön, dem Treßsee Kr. Schleswig-Flensburg und dem Ilewitter Moor, Kr. Rendsburg-Eckernförde. Dissertation, Universität Kiel. Universitätsforschungen zur Prähistorischen Archäologie 45; Bonn (Habelt Verlag).

Welinder, S. 1985: Mesolithic Forest Clearance in Scandinavia. - In: Bonsall, C. (ed.): The Mesolithic in Europe. Papers presented at the $3^{\text {rd }}$ international Symposium, Edinburgh 1985: 362-366; Edinburgh (Donald).

Weninger, B., Schulting, R., Bradtmöller, M., Clare, L., Collard, M., Edinborough, K., Hilpert, J., Jöris, O., Niekus, M., Rohling, E.J. \& WAgner, B. (2008): The catastrophic final flooding of Doggerland by the Storegga Slide tsunami. - Documenta Praehistorica XXXV: 1-24.
Whitehead, H. ひ Goodchild, H.H. (1909): Some Notes on "Moorlog", a Peaty Deposit from the Dogger Bank in the North Sea. - Essex Naturalist XVI: $51-60$.

Wolters, S., Zeiler, M. \& Bungenstock, F. (2010): Early Holocene environmental history of sunken landscapes: pollen, plant macrofossil and geochemical analyses from Borkum Riffgrund, southern North Sea. - International Journal of Earth Science 99: 1707-1719 